\title{
Inhibin and oestradiol in the control of FSH secretion in the sheep
}

\author{
D. T. Baird, B. K. Campbell, G. E. Mann and A. S. McNeilly* \\ Department of Obstetrics and Gynaecology and $* M R C$ Unit of Reproductive Biology, Centre for \\ Reproductive Biology, University of Edinburgh, 37 Chalmers Street, Edinburgh EH3 9EW, UK
}

\begin{abstract}
Summary. In the sheep both FSH and LH are necessary for development of large antral follicles. The secretion of FSH is controlled by the negative feedback effect of two ovarian hormones, oestradiol and inhibin, acting at the level of the anterior pituitary. Both are derived from the granulosa cells of large antral follicles which are present in sheep ovaries throughout the oestrous cycle. FSH stimulates growth and mitosis and so the fully differentiated granulosa cells of the large preovulatory follicles acquire receptors for $\mathrm{LH}$, have maximal aromatase activity and produce large amounts of inhibin. The number of these large antral follicles (oestrogenic) which have the potential for ovulation corresponds to the ovulation rate specific for each particular breed of sheep. Over $90 \%$ of the oestradiol secreted by the ovaries is derived from these chosen follicles. In contrast, inhibin (and androstenedione) is also secreted by large antral follicles which have lost or not yet acquired maximal aromatase activity.

The secretion of oestradiol by the preovulatory follicle(s) is dependent on the supply of androgen precursors produced by the theca which is stimulated by LH. When the concentration of progesterone falls at the end of the luteal phase the increased secretion of LH stimulates the progressive increase in secretion of oestradiol which occurs during the follicular phase. At this stage of the cycle there is a modest inconsistent rise in inhibin, the secretion of which is not stimulated by $\mathrm{LH}$ but is related to the increase in the number of large antral follicles. It is suggested that inhibin with its long half-life sets the overall level of negative feedback while oestradiol is responsible for the day-to-day fluctuations in the concentration of FSH which determines the number of ovulatory follicles. This dual control of FSH is adapted to monitor both the total number of large antral follicles in the ovaries (inhibin) and the number which are selected for ovulation (oestradiol).
\end{abstract}

Keywords: inhibin; oestradiol; FSH; sheep

\section{Introduction}

The development of antral follicles is dependent on the secretion of pituitary gonadotrophins, as indicated by the absence of healthy antral follicles after hypophysectomy (Dufour et al,, 1979). In the sheep, large antral follicles develop at all stages of the oestrous cycle but only progress through the final preovulatory maturation during the follicular phase (Baird \& McNeilly, 1981). It is thought that selection of the follicle(s) which will ovulate occurs in the early follicular phase from amongst the pool of small antral follicles $(\sim 2 \mathrm{~mm}$ in diameter) which are present in the ovaries at this time. Although the mechanism responsible for this selection is not entirely clear, it probably involves FSH and LH as well as local paracrine factors within the ovary. The fall in the concentration of FSH which occurs during the follicular phase plays a key role in limiting the number of follicles which eventually ovulate (Baird, 1983). In this paper we shall consider the factors regulating the secretion of FSH throughout the oestrous cycle in the sheep. It is our hypothesis that the 
concentration of FSH determines the number of follicles ovulated, and therefore control of its secretion is a crucial element in reproductive activity in the sheep.

\section{Secretion of FSH}

FSH is synthesized in the gonadotrophs of the anterior pituitary, probably in the same cell which synthesizes LH. The secretion of both gonadotrophins is stimulated by gonadotrophin-releasing hormone $(\mathrm{GnRH})$, although the synthesis of FSH continues even in the absence of pulsatile stimulation (McNeilly, 1988). For example, administration of antiserum to GnRH or a potent antagonist of GnRH results in a rapid and prolonged suppression of LH pulses (McNeilly et al., 1984; Campbell et al., 1990b). However, the concentration of FSH remains constant or even rises due to the fall in the secretion of oestradiol. The secretion of FSH is therefore directly related to its rate of synthesis while that of $\mathrm{LH}$ is dependent on synthesis and release.

\section{The effect of oestradiol and inhibin on FSH concentration}

It has been known for many years that injection of oestradiol (Salamonsen et al,, 1973; Jonas et al., 1973) or crude preparations of 'inhibin' (e.g. bovine follicular fluid) causes a suppression in the concentration of FSH in sheep (Miller et al., 1982; McNeilly, 1984; Al-Obaidi et al., 1986). However, these studies involved the injection of large amounts of hormone and/or crude preparations of inhibin (usually follicular fluid treated with charcoal to remove steroids) and, so their physiological relevance is uncertain. When purified inhibin became available it was demonstrated that injection into ovariectomized ewes caused suppression of FSH (Findlay \& Clarke, 1987). Having established that both hormones (oestradiol and inhibin) which were known to be secreted by the ovary can suppress FSH, it remains to answer the question as to their relative contribution throughout the oestrous cycle. In a series of careful experiments it has been demonstrated that the rise in FSH which occurs immediately after bilateral ovariectomy could not be prevented by implants which released physiological amounts of oestradiol (Goodman et al., 1981). The model used is more appropriate than that involving long-term oyariectomized animals in which the secretion of gonadotrophins is grossly elevated.

Martin et al. (1988) used this model to investigate the effect of different amounts of oestradiol and ovine follicular fluid ('inhibin') alone and in combination on the concentration of FSH. Progesterone alone or in combination with other hormones had no influence on the secretion of FSH in this model. Physiological amounts of oestradiol or inhibin were ineffective at preventing the rise in FSH concentration after ovariectomy. However, when a combination of both was given in amounts known to be secreted by the ovary in vivo at the time of ovariectomy, the concentration of FSH remained within the range found in the intact animal. Follicular fluid contains other hormones (e.g. activin) which may influence the secretion of FSH, although it is likely that the amounts present are less than $20 \%$ that of inhibin. It would be of interest to reinvestigate the problem in this model using pure inhibin.

It is, however, proper to be cautious before considering the physiological significance of these elegant experiments. Although the total amount of inhibin and oestradiol administered was within the range secreted by the intact ewe, both hormones are known to be secreted from the ovaries in a pulsatile manner (McNeilly \& Baird, 1989). In the rat it has been demonstrated that the feedback effect of progesterone on the hypothalamus differs depending on whether it is given by constant infusion or in the form of intermittent pulses (Dluzen \& Ramirez, 1987). We have no information for the sheep as to whether constant administration of oestradiol (as in these experiments) has a similar negative feedback effect on the secretion of FSH as does pulsatile secretion such as occurs from the ovary.

In these experiments progesterone apparently had no effect on the secretion of FSH. However, progesterone receptors are present in sheep pituitary glands and progesterone (as well as oestradiol 
and inhibin) suppresses the release of FSH from dispersed sheep pituitary cells in physiological concentrations $\left(10^{-8} \mathrm{M}\right.$ ) (Miller et al, 1977; Tsonis et al., 1986). It is possible, therefore, that in the intact ewe progesterone may contribute in some way to the feedback control of FSH. Studies involving passive immunization would help to clarify this point.

\section{Effect of immunization}

If inhibin and/or oestradiol are involved in the negative feedback system, then immunization against these ovarian hormones should result in a change in the secretion of FSH. The concentration of FSH and $\mathrm{LH}$ is markedly elevated following active immunization against conjugates of oestradiol and there is evidence of multiple follicular development, although ovulation does not occur due to failure of oestradiol to induce the positive feedback signal (Pant \& Rawlings, 1973; Martensz et al., 1979). More recently there have been several reports of an increase in ovulation rate following active immunization against 'inhibin' (Henderson et al., 1984; Cummins et al., 1986; Findlay et al, 1989; Wrathall et al., 1990). However, in these studies a rise in the concentration of FSH was either not detected or modest, and confined to particular stages of the cycle. It is presumed that the ovary rapidly responds to immunization by increasing the secretion of oestradiol and other possible inhibitory substances so that the level of FSH is restored to a value within the normal range.

We have investigated the role of oestradiol and inhibin in the regulation of FSH in the intact ewe by passive immunization with specific antisera at specific stages of the cycle (Mann et al., $1989 \mathrm{~b}, 1990)$. By following the acute changes in the concentration of FSH immediately after the injection of antisera, we have been able to determine the effects of acute perturbation of the feedback system.

There is a significant rise in the concentration of FSH after injection of antisera to oestradiol and inhibin during both the follicular and luteal phases of the cycle. The maximum rise of about $50 \%$ above baseline occurs within $12 \mathrm{~h}$ and is sustained for longer after injection of antiserum to oestradiol. When both antisera are injected in combination the rise in FSH is significantly greater and simulates that seen after ovariectomy. We can conclude from these experiments that oestradiol and inhibin are probably the major ovarian hormones involved with the control of FSH secretion in the sheep oestrous cycle. As the rise in the concentration of FSH after immunization against both hormones is similar to that after ovariectomy, it is unlikely that there are other as yet unrecognized ovarian hormones involved in this feedback mechanism.

\section{Source of inhibin secretion in the sheep}

What is the origin of inhibin secreted by the ovary? Inhibin is present in high concentration in follicular fluid of all species tested including the sheep, suggesting that the follicle is a major source (Tsonis et al., 1984). Recent data have shown that sheep granulosa cells release inhibin into the medium when cultured in vitro although the amount declines in parallel with that of oestradiol within a few days (Campbell, 1989). mRNA for the $\alpha$-subunit of inhibin is expressed in granulosa cells of antral follicles but not in appreciable amounts in the corpus luteum or stroma (Rodgers $e t$ al., 1989). These results suggesting that antral follicles are the major source of inhibin in the sheep have received additional support from the measurement of inhibin secretion in vivo. The concentration of inhibin in ovarian effluent lymph or venous blood falls after enucleation or cautery of the large antral follicles (Findlay el al., 1986, 1990). The secretion of inhibin is 10-fold higher from an ovary containing large antral follicles than from the contralateral side which contains follicles $<3 \mathrm{~mm}$ in diameter (Fig. 1) (Mann et al., 1989a). These studies strongly suggest that the large antral follicles are the major if not sole source of inhibin in the sheep. 
It had previously been suggested that the sheep corpus luteum (like that of women and primates) might secrete inhibin (Tsonis et al., 1988a, b). This conclusion was based on experiments in which it was found that the concentration of bioactive inhibin was higher in ovarian venous blood draining ovaries containing one or more corpora lutea than that draining ovaries without corpora lutea. However, in this experiment samples were obtained from ewes which had been immunized against androstenedione as well as from control ewes. As immunization increases the ovulation rate, it is likely that the immunized ewes were over-represented in the samples draining corpora lutea (Scaramuzzi et al., 1977). It is known that the secretion rate of inhibin is increased in androstenedione-immunized ewes due to the increased number of large antral follicles (Campbell et al., 1990a).
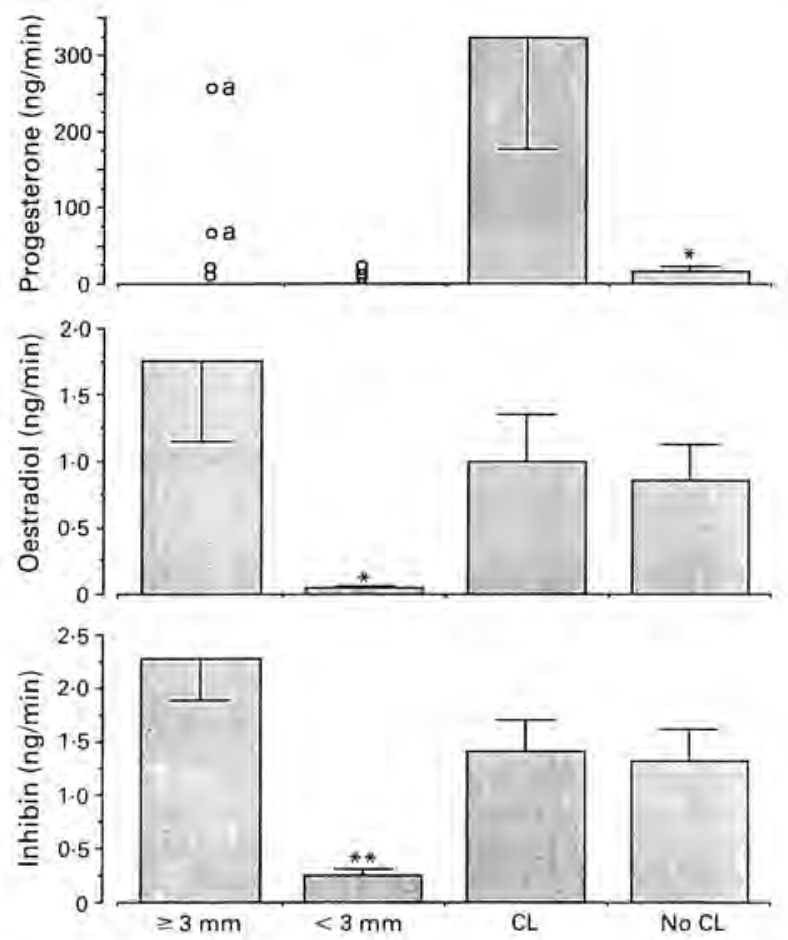

Fig. 1. Secretion of inhibin, oestradiol and progesterone by Blackface ewes after cannulation in situ of ovarian veins. The secretion of inhibin and oestradiol was significantly higher from ovaries which contained large follicles $(n=4)$ (diameter $\geq 3 \mathrm{~mm}$ ) There was no difference in the secretion rate of oestradiol or inhibin between ovaries with and without corpora lutea $(n=11)$ (a= ovary also contained corpus luteum). ${ }^{*} P<0.05 ; * *<00 \cdot 01$. (From Mann et al., 1989a.)

We have repeated these experiments with Blackface ewes in which the secretion rates of inhibin, oestradiol and progesterone from each ovary were measured in the same ewe (Mann et al., 1989a). There was no difference in the secretion rate of inhibin or oestradiol between ovaries with and without corpora lutea (Fig. 1). Following enucleation of the corpus luteum, as expected there was a profound fall in the secretion of progesterone. In contrast, the fall in the secretion of inhibin and oestradiol was similar (about $50 \%$ ) and could be accounted for by the trauma of enucleation and the effect of general anaesthesia. As the sheep corpus luteum secretes no oestradiol, these findings strongly suggest that inhibin, like oestradiol, is secreted solely by antral follicles and that the previous suggestion of a luteal source was due to defects in the experimental design. 


\section{Secretion of ovarian hormones and FSH throughout the oestrous cycle}

The studies mentioned above have established that both oestradiol and inhibin can suppress. FSH in the sheep and that they both play some role in the control of FSH secretion in the intact ewe. What is known about their secretion by the ovary at different stages of the cycle? Oestradiol is derived exclusively from the antral follicles in the sheep with over $90 \%$ being secreted by the large preovulatory follicle(s) (Baird \& Scaramuzzi, 1976). The amount of oestradiol secreted by the ewe is very low (maximum about $10 \mu \mathrm{g}$ per day) and, hence, the concentration in peripheral blood so low (about $1-10 \mathrm{pg} / \mathrm{ml}$ ) that it is very difficult to measure accurately. We have preferred to measure the ovarian secretion directly either by cannulating the ovarian veins in situ or by autotransplanting the ovary with its vascular pedicle to the neck where the venous effluent can be sampled repeatedly in the conscious unstressed animal by percutaneous cannulation (Goding et al, 1967; Baird et al,, 1976a). We have used this preparation to relate the secretion rate of ovarian steroid hormones (oestradiol, androstenedione and progesterone) and inhibin at different stages of the cycle to the concentration of FSH and LH in jugular venous plasma collected simultaneously (Figs 2 and 3) (Campbell et al., 1990c).

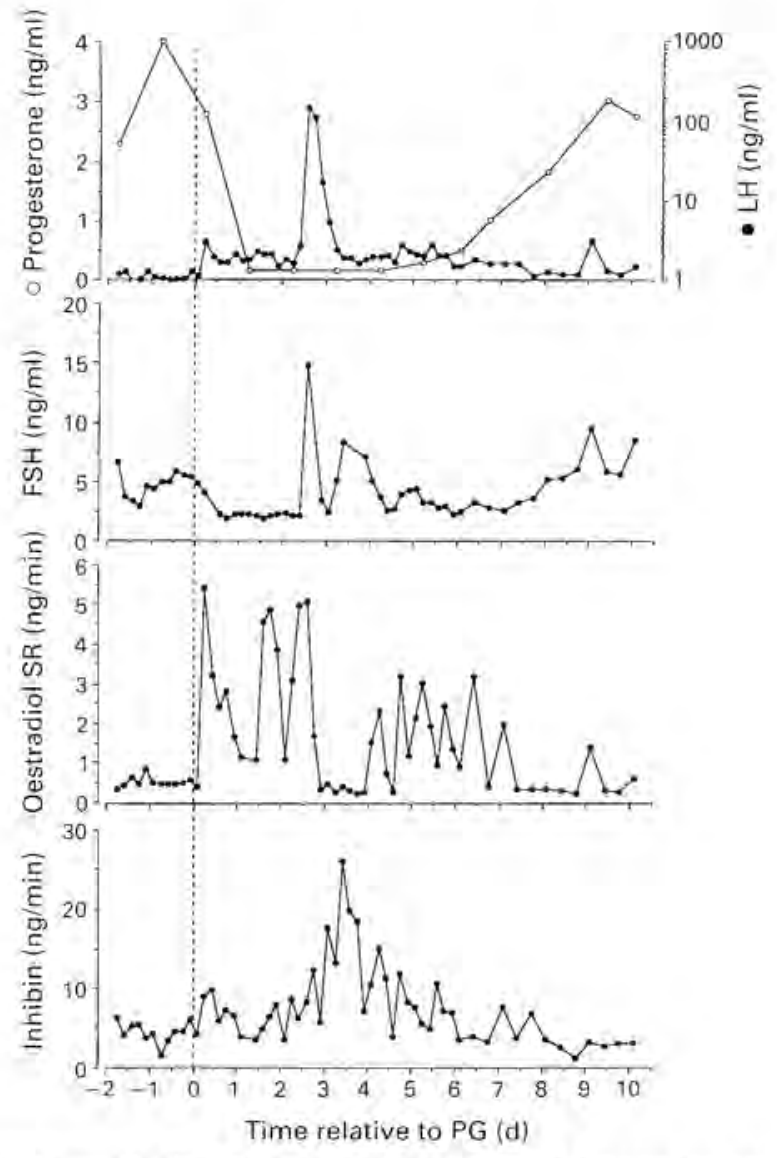

Fig. 2. The concentration of LH, FSH and progesterone and the ovarian secretion of oestradiol and inhibin from a ewe with an ovarian autotransplant. The samples have been grouped around the injection of $100 \mu \mathrm{g}$ cloprostenol (PG) on Day 10 of the cycle in order to induce luteal regression. In this ewe the maximum secretion of inhibin occurred at $84 \mathrm{~h}$ after the injection of cloprostenol and coincided with the second peak of FSH about the time that ovulation would have occurred. (Data from Campbell et al., 1990c). 


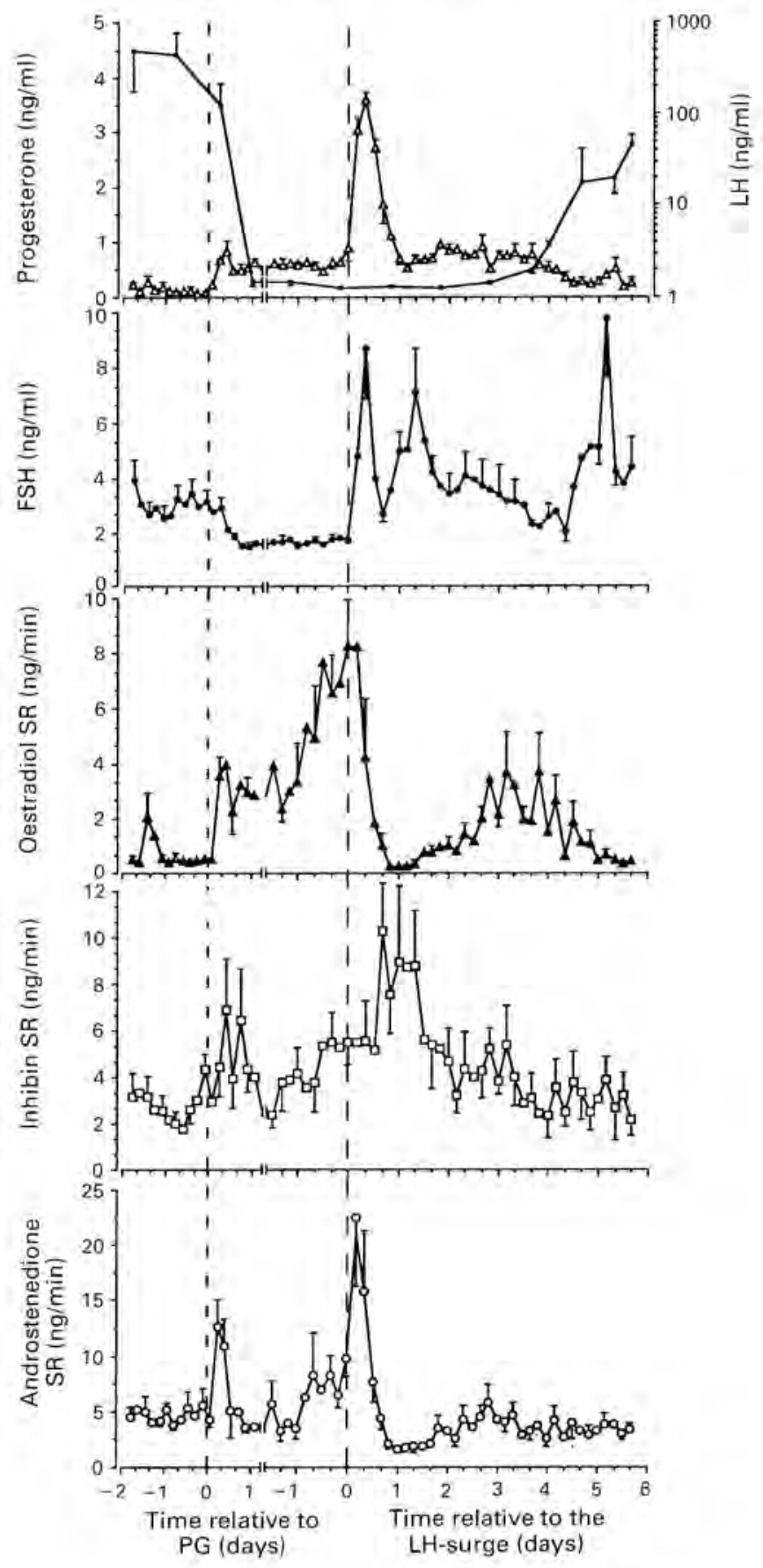

Fig. 3. The concentration of progesterone, $\mathrm{LH}$ and FSH in jugular venous plasma and the ovarian secretion (SR) of oestradiol, inhibin and androstenedione in 6 Finn-Merino ewes with ovarian autotransplants. The samples have been grouped around the time of injection of $100 \mathrm{\mu g}$ cloprostenol (PG) on Day 10 of the cycle and relative to the onset of the LH surge (at $64 \pm 2 \mathrm{~h}$, mean \pm s.e.m.). The values are expressed as mean \pm s.e.m. (Campbell et al., 1990c.) 
During the luteal phase the secretion of oestradiol varies considerably from day to day. This variation is due to two main factors: firstly, the secretion is pulsatile, being acutely sensitive to fluctuations in the concentration of LH (Baird \& McNeilly, 1981). Following each pulse of LH there is an immediate increase in the secretion of oestradiol (and its precursor androstenedione). As LH pulses occur at rather infrequent intervals during the luteal phase (about every $6 \mathrm{~h}$ ) the overall secretion of oestradiol is much lower than during the follicular phase (Baird et al., 1976b). Secondly, most of the oestradiol secreted by the ovary is derived from the large healthy antral follicles ( $>4 \mathrm{~mm}$ in diameter) the numbers of which vary from day to day throughout the luteal phase (Smeaton \& Robertson, 1971). Those waves of follicular development that occur at approximately 4-day intervals appear to follow peaks in the concentration of FSH. It is tempting to postulate that the first wave on Day 3 or 4 is a consequence of recruitment of small antral follicles by the rise in FSH concentration which occurs on Day 1 about $18 \mathrm{~h}$ after the preovulatory LH surge ('second FSH peak'). Thus as the cohort of large antral follicles develop, the secretion of oestradiol rises and suppresses the concentration of FSH.

When the concentration of progesterone falls during regression of the corpus luteum, the concentration of LH rises due to an increase in the frequency of LH pulses (Baird, 1978). By $24 \mathrm{~h}$ after luteal regression each hourly LH pulse stimulates the secretion of oestradiol by the ovary. Thus the integrated secretion of oestradiol by the ovary rises markedly and induces by positive feedback the preovulatory surge of LH.

The secretion of inhibin varies much less than that of oestradiol throughout the oestrous cycle. During the follicular phase there is a 2 -fold rise in the secretion of inhibin although the pattern is highly variable and is not seen in every ewe (Fig. 3). Recent data have thrown light on the reason for the differences in the pattern of secretion between inhibin and oestradiol (Campbell et al,, 1990d). Although both hormones are derived from antral follicles, there are some large follicles which secrete very little oestradiol but appreciable amounts of inhibin (and androstenedione). Large 'oestrogenic' follicles which secrete oestradiol as well as inhibin are presumed to be those which have the potential to ovulate while the former are probably in the process of atresia having lost aromatase activity. Thus the amount of inhibin secreted by the ovary during the follicular phase is determined by the total population of large antral follicles which exists at the time of luteal regression.

Another factor relevant to the secretion of inhibin and oestradiol relates to the effects of gonadotrophins. The secretion of oestradiol is dependent on the supply of androgen precursor so that each pulse of LH stimulates increasing amounts of oestradiol (Baird \& McNeilly, 1981). In contrast, although the secretion of inhibin by the ovary is episodic, these pulses are not related temporarily to LH, oestradiol or FSH (McNeilly \& Baird, 1989; Campbell et al., 1990a). Injection of $\mathrm{LH}$ or FSH in amounts equivalent to the maximum found physiologically results in no significant change in the secretion of inhibin by the ovary over the next $6 \mathrm{~h}$ (Campbell et al., 1989). The increase in the secretion of inhibin and oestradiol observed when large amounts of FSH are injected is probably related to the increase in the number of large antral follicles rather than to the stimulation of the granulosa cells of individual follicles (Tsonis et al., 1988a; McNeilly et al., 1991).

We know nothing about the factors which regulate the amount of inhibin secreted by individual follicles. The concentration of inhibin in follicular fluid is extremely high $(\sim 10000 \mathrm{Units} / \mathrm{ml})$ and is several hundred-fold higher than that in ovarian venous blood. There are several different molecular species of inhibin in follicular fluid ranging from proteins of $M_{\mathrm{r}} 32000$ to $>100000$ (Miyamoto et al., 1985; Leversha et al., 1987). It is not known what form of inhibin is secreted into ovarian venous blood in the sheep although apparently there is little, if any, free $\alpha$-subunit (Knight et al., 1989). The fact that non-oestrogenic large follicles secrete inhibin may indicate that one of the factors limiting the secretion of inhibin from a follicle is the permeability of the basement membrane between the granulosa and theca layers.

Thus, although both inhibin and oestradiol are secreted by the granulosa cells of large preovulatory follicles, the secretion of the former is not acutely sensitive to changes in the concentration of 
LH. In the rat, FSH induces aromatase activity and inhibin production by granulosa cells cultured in vitro (Bicsak \& Hsueh, 1988). Therefore although FSH is required for full differentiation of the granulosa cells such as exists in the mature preovulatory follicle, it seems unlikely that it determines the amount of hormone secreted from minute to minute. We know very little about the factors which determine the amount of inhibin secreted by an individual follicle in vivo although the total ovarian secretion is related to the number of large follicles in the ovaries.

\section{Relationship between ovarian secretion of inhibin and oestradiol and FSH concentration}

How do the observed changes in the secretion of ovarian steroids and inhibin correlate with the cyclic fluctuations in the concentration of FSH? It has been already noted that the peaks in FSH concentration which occur at approximately 4-day intervals throughout the luteal phase coincide to periods when there is minimal secretion of inhibin and oestradiol (McNeilly et al., 1989). During this phase of the cycle there is an inverse relationship between the concentration of FSH and the secretion of both oestradiol and inhibin in keeping with the hypothesis that both hormones contribute to the inhibition of FSH. The decline in the concentration of FSH during the follicular phase is also accompanied by a rise in the secretion of both oestradiol and inhibin (Findlay et al., 1990; Campbell et al., 1990c). However, the rise in the secretion of inhibin varies considerably between animals, in contrast to the marked increase in the secretion of oestradiol which occurs consistently in every ewe. At this stage of the cycle, therefore, although both hormones contribute to negative feedback, oestradiol plays a more important role in causing further suppression in the secretion of FSH which occurs in the mid-and late follicular phase. This suppression of FSH appears to play a crucial role in determining the number of follicles which will eventually ovulate. In high fertility breeds, e.g. Finnish Landrace which consistently ovulate 2 or 3 follicles, the hypothalamicpituitary unit appears to be more resistant to negative feedback and the suppression of FSH is at a lesser degree and occurs later in the follicular phase than in less prolific breeds (Land, 1976; Bindon et al., 1979).

By $24 \mathrm{~h}$ after luteal regression all the large antral follicles other than those which will ovulate have become atretic (McNatty et al., 1982). It must be assumed that the ovulatory follicle(s) become increasingly less dependent on FSH in the $48 \mathrm{~h}$ before ovulation, while the less favoured follicles become atretic when the level of FSH falls below the 'threshold'. If the concentration of FSH is maintained above the threshold by infusion of exogenous FSH many more large follicles remain healthy and are available for ovulation (McNatty et al., 1982). However, in the spontaneous cycle the ovulatory follicle(s) has a certain minimal requirement for FSH. If the concentration of FSH is suppressed further by injection of follicular fluid in the mid-follicular phase of the cycle, the secretion of ovarian steroids and inhibin is totally inhibited and further follicular development ceases (McNeilly, 1985; Baird et al., 1990). The concentration of FSH is thus kept within a normal range, below that required to activate or recruit small antral follicles but above that necessary to maintain the development of the ovulatory follicle(s).

\section{Second FSH peak}

About 50-60 h after luteal regression induced by injection of prostaglandin, the increased oestradiol secretion from the ovary provokes a massive surge of LH which is responsible for ovulation about $24 \mathrm{~h}$ later. A peak of FSH occurs coincidental to the LH surge which is thought to be dependent on release of $\mathrm{GnRH}$ from the hypothalamus because it can be inhibited by antagonists of or antiserum to GnRH (Narayana \& Dobson, 1979). In contrast, the second peak of FSH which occurs about $18 \mathrm{~h}$ later cannot be inhibited by immunoneutralization of GnRH and is thought to be due to relative lack of feedback at the level of the anterior pituitary. Within $6 \mathrm{~h}$ of the start of the 
LH surge there is a marked decline in the secretion of oestradiol and androstenedione and by the time of the second FSH peak the secretion of ovarian steroids is lower than at any other stage of the cycle (Fig. 3). In contrast, the secretion of inhibin remains high over this period and only falls at about the time ovulation.

The close inverse relationship between the secretion of oestradiol by the ovary and the concentration of FSH is illustrated in experiments in which the secretion of oestradiol was first stimulated and then inhibited by the infusion of LH during the luteal phase of the cycle (Baird et al., 1980). When $1.25 \mathrm{mg}$ ovine LH (NIH-LH-S-17) were infused over $6 \mathrm{~h}$ into the jugular vein of 3 FinnMerino ewes with either utero-ovarian or ovarian autotransplants on Day 10 of the luteal phase, there was a marked rise in the concentration of $\mathrm{LH}$ which simulated a preovulatory $\mathrm{LH}$ surge both in size and duration. In all ewes there was an immediate increase in the secretion of oestradiol within a few minutes of starting the LH infusion. The increase, however, was not sustained and within $3 \mathrm{~h}$ the secretion of oestradiol declined to reach basal levels $(<2 \mathrm{ng} / \mathrm{min})$ by $9 \mathrm{~h}$ after the start of the infusion. The pattern of secretion of androstenedione and testosterone was similar to that of oestradiol. Figure 4 illustrates the changes in the concentration of FSH, $\mathrm{LH}$ and prolactin and in the secretion of oestradiol in a single ewe with a utero-ovarian autotransplant. The concentration of FSH started to fall about the end of the infusion and reached a nadir by about $9 \mathrm{~h}$. There was then a progressive rise in the concentration of FSH which did not fall until the secretion of oestradiol rose again about $26 \mathrm{~h}$ after the start of the $\mathrm{LH}$ infusion.

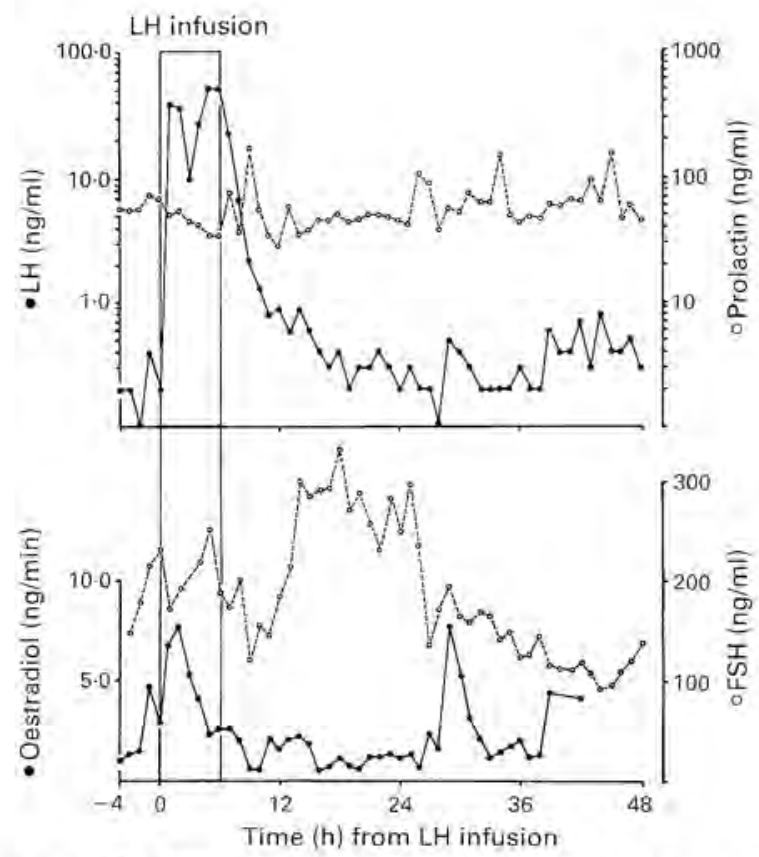

Fig. 4. Concentrations of LH, FSH and prolactin and ovarian secretion of oestradiol in a ewe with utero-ovarian autotransplant on Day 10 of the cycle: $1.25 \mathrm{mg}$ ovine LH (NIH-LH-S-17) were infused over $6 \mathrm{~h}$ as indicated. (From Baird et al., 1980.)

These experiments, demonstrating the reciprocal relationships between the secretion of oestradiol and FSH, strongly support the hypothesis that the second peak of FSH which occurs about $24 \mathrm{~h}$ after the start of the LH surge at about the time of ovulation in the spontaneous cycle is due to the very low level of oestradiol secretion at this time (Baird et al., 1981). Moreover, because the secretion of androstenedione and testosterone were also suppressed, they demonstrate that the 
inhibition of secretion of oestradiol which follows the LH surge is probably due to desensitization in the theca cells (Webb \& England, 1982). These findings suggest that the second peak of FSH in the sheep is due to lack of negative feedback of oestradiol rather than inhibin as has been suggested for the rat (Chappel \& Barraclough, 1977). However, it is possible that the immunoactive material measured with the inhibin radioimmunoassay is free $\alpha$-subunit or some other molecule which is without biological activity. Free $\alpha$-subunit is present in high concentrations in the cow although it was reported to be absent in sheep follicular fluid and venous effluent blood (Knight et al,, 1989; Sugino et al., 1989). However, it is possible that around the time of ovulation a different form of inhibin-like molecule is released from the ovary which is biologically inactive. Studies measuring bioactive and immunoactive inhibin at carefully timed intervals in the periovulatory period would help clarify this issue.

After the second FSH peak the concentrations of FSH decline gradually until Day 4 or 5 of the cycle. At this stage the secretion of inhibin also declines and the two hormones are positively correlated. In contrast, there is a consistent rise in the secretion of oestradiol at this time reflecting the growth and development of a cohort of follicles which reach a maximum diameter on about Day 4.

In summary, at all stages of the cycle there is a negative correlation between the secretion of oestradiol and the concentration of FSH (Fig. 5). During the early follicular phase inhibin and FSH show a similar negative relationship, although at other stages of the cycle, e.g. early luteal phase, the two parameters are positively correlated. Therefore, although inhibin can inhibit the secretion of FSH and contributes to the overall level of negative feedback, it seems likely that the day-to-day fluctuations in the pattern of FSH which play a crucial role in determining the recruitment of ovulatory follicles are determined by the secretion of oestradiol. There are several advantages to this mechanism. Firstly, because the granulosa cells of the preovulatory follicle(s) have already acquired maximal aromatase activity (induced by FSH) the amount of oestradiol secreted in the follicular phase is determined by the supply of androgen precursor. As this is produced by the theca cells under stimulation by $\mathrm{LH}$, the amount of oestradiol is determined not by FSH but by $\mathrm{LH}$. Thus the follicle is able to break out of the negative feedback loop involving FSH and ovarian steroids for the time required to secrete enough oestrogen to induce an $\mathrm{LH}$ surge. If the amount of oestradiol secreted by the follicle was only dependent on FSH, the negative feedback loop would ensure that the secretion of oestradiol oscillated around the levels found during the luteal phase.

The fact that inhibin secretion reflects the total antral follicle population within the ovaries, and not solely the dominant follicle(s), may provide a basal level of negative feedback which dampens wild swings in the concentration of FSH. As significant quantities of oestradiol are only secreted by dominant follicles, the secretion of FSH would be very high during periods of follicular quiescence in the absence of inhibin. The high levels of FSH would then stimulate multiple follicular development, oestrogen secretion and subsequent suppression of FSH.

There are marked differences in the rate at which oestradiol and inhibin are removed from the blood which may have an impact on their different roles in regulating FSH. Due to its long metabolic clearance rate $(\mathrm{MCR})(20-30 \mathrm{ml} / \mathrm{min})$ any alteration in the secretion of inhibin results in a relatively slow change in the peripheral concentration (McNeilly \& Baird, 1989). In contrast, the clearance of oestradiol is very rapid (MCR $\sim 2000 \mathrm{ml} / \mathrm{min}$ ) (Challis et al,, 1970) and changes in secretion are reflected very rapidly by changes in the peripheral circulation and. hence, the degree of negative feedback. Thus oestradiol is a more appropriate ovarian signal to produce a relatively rapid change in the degree of negative feedback, i.e. to suppress the secretion of FSH below the threshold level in the follicular phase while the very long half-life of inhibin makes it more suitable for setting the overall level of feedback.

In view of the fact that the secretion of inhibin reflects the total population of large antral follicles while the secretion of oestradiol reflects the number of dominant follicles, one might expect differences in the secretion of inhibin in breeds of differing prolificacy such as occurs in the ram 


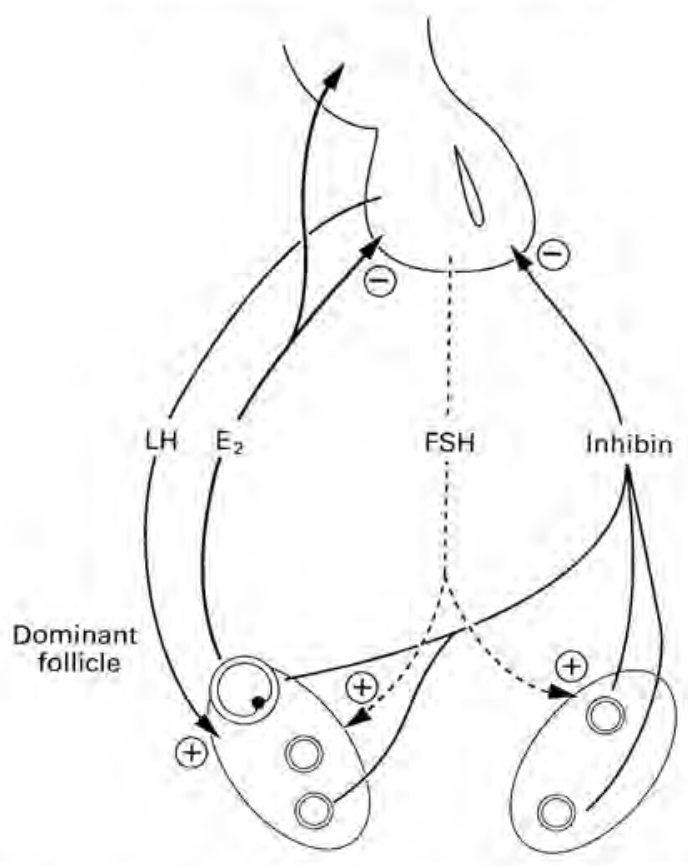

Fig. 5. Hypothalamic-pituitary-ovarian relationships in the follicular phase of the oestrous cycle in the sheep. The dominant follicle(s) secretes oestradiol $\left(\mathrm{E}_{2}\right)$ and inhibin which is also produced by large 'non-oestrogenic' follicles. Both hormones suppress the release of FSH from the anterior pituitary. While oestradiol reduces the amplitude of $\mathrm{LH}$ pulses it has no effect on frequency and, hence, stimulates the production of thecal androgens and the secretion of oestradiol.

(Lincoln et al., 1990). Preliminary data suggest that Booroola Merino ewes (+F or FF) carrying the high fecundity gene secrete the same amount of oestradiol and inhibin as those without the gene $(++)$ (Tsonis et al., 1988c). The preovulatory follicles of the $+F$ ewes are smaller and contain fewer granulosa cells than in ++ controls (Baird et al., 1982). As each preovulatory follicle in the FF ewes secretes smaller amounts of oestradiol and inhibin, the combined ovarian secretion is similar to that in the ewes with a single preovulatory follicle. This probably reflects the fact that the total number of granulosa cells from the combined preovulatory follicles in the FF ewes is similar to that found in the single preovulatory follicle of the control ++ ewes. Whether there are differences in inhibin secretion in other high fecundity breeds of sheep remains to be determined.

We thank Nora Anderson and Joan Docherty for the care of animals; Ian Miller, Wendy Crow, Helen Picton and Linda Harkness for technical assistance; Ted Pinner and Tom McFetters for graphics; and Margaret Harper for typing the manuscript. This work was supported by MRC Programme Grant No. 8426375. B.K.C. was supported by a CSIRO Post Doctoral award.

\section{References}

Al-Obaidi, S.A.R., Bindon, B.M., Hill, A.A., O'Shea, T. \& Piper, L.A. (1986) Suppression of ovine plasma FSH by bovine follicular fluid: neutralization by plasma from ewes immunized against an inhibinenriched preparation from bovine follicular fluid. J. Endocr. 111, 1-5.
Baird, D.T. (1978) Pulsatile secretion of LH and ovarian oestradiol in the follicular phase of the sheep estrous cycle. Biol. Reprod. 18, 359-364.

Baird, D.T. (1983) Factors regulating the growth of the preovulatory follicle in the sheep and human. J. Reprod. Fert. 69, 343-352. 
Baird, D.T. \& Scaramuzzi, R.J. (1976) The source of ovarian oestradiol and androstenedione in the sheep during the luteal phase. Acta endocr., Copenh. 83, 402-409.

Baird, D.T. \& McNeilly, A.S. (1981) Gonadotrophic control of follicular development and function during the oestrous cycle of the ewe, J. Reprod. Ferl., Suppl, 30, $119-133$.

Baird, D.T., Land, R.B., Scaramuzzi, R.J. \& Wheeler, A.G. (1976a) Functional assessment of autotransplanted uterus and ovary in the ewe. Proc, $R$. Soc. $B$ 192, 463-474.

Baird, D.T., Swanston, I.A. \& Scaramuzzi, R.J. (1976b) Pulsatile secretion of LH and secretion of ovarian steroids in the sheep during the luteal phase of the estrous cycle, Endocrinology 98, 1490-1496.

Baird, D.T., McNeilly, A.S., O'Connell, M.A \& Swanston, I.A. (1980) the role of LH and oestradiol in the regulation of FSH secretion in the sheep. Proc. 6 th Int. Congr. Endocrinol., Melbourne, Abstract No. 892.

Baird, D.T., Swanston, I.A. \& McNeilly, A.S. (1981) Relationship between LH, FSH and prolactin concentration and the secretion of androgens and estrogens by the pre-ovulatory follicle of the ewe. Biol. Reprod. 24, 1013-1025.

Baird, D.T., Ralph, M.M., Seamark, R.F., Amato, F. \& Bindon, B.M. (1982) Pre-ovulatory follicular activity and estrogen secretion of high (Booroola) and low fecundity Merino ewes. Proc. Aust. Soc. Reprod. Biol. 14, abstr, 83.

Baird, D.T., Campbell, B.K. \& McNeilly, A.S. (1990) Ovine follicular fluid suppresses the ovarian secretion of androgens, oestradiol and inhibin. J. Endoer. 127, (in press).

Bicsak, T.A. \& Hsueh, A.J.W. (1988) Recent advances in Inhibin Research. In The Primate Ovary, pp. 35-47. Ed. R. L. Stouffer, Plenum Press, New York.

Bindon, B.M., Blanc, M.R., Pelletier, J., Terqui, M. \& Thimonier, J. (1979) Periovulatory gonadotrophin and ovarian steroid patterns in sheep of breeds with differing fecundity. J. Reprod. Fert. 55, 15-25.

Campbell, B.K. (1989) Inhibin, oestradiol and progesterone production by ovine granulosa cells in vitro. $J$. Reprod. Fert., Abstr. Ser. 3, p. 24.

Campbell, B.K., McNeilly, A.S. \& Baird, D.T. (1989) Episodic ovarian inhibin secretion is not due to LH pulses in anoestrous ewes. J. Endocr. 123, 173-179.

Campbell, B.K., Baird, D.T., McNeilly, A.S. \& Scaramuzzi, R.J. (1990a) Inhibin: ovarian secretion rates and peripheral concentrations in normal and androstenedione-immune ewes with an autotransplanted ovary. J. Endocr. (in press).

Campbell, B.K., MeNeilly, A.S., Picton, H.M. \& Baird, D.T. (1990b) Effect of a potent GnRH antagonist on ovarian secretion of oestradiol, inhibin and androstenedione and the concentration of $\mathrm{LH}$ and $\mathrm{FSH}$ during the follicular phase of the sheep oestrous cycle. J. Endocr. 126, 377-384.

Campbell, B.K., Mann, G.E., McNeilly, A.S. \& Baird, D.T. (1990c) The pattern of ovarian inhibin, estradiol and androstenedione secretion during the estrous cycle of the ewe. Endocrinology 127, 227-235,

Campbell, B.K., McNeilly, A.S., Mann, G.E. \& Baird, D.T. (1990d) The effect of stage of estrous cycle and follicular maturation on ovarian inhibin production in sheep. Biol. Reprod. (in press).

Challis, J.R.G., Harrison, F.A. \& Heap, R.B. (1970) Metabolic clearance rate and conversions of oestradiol-17 $\beta$ in the sheep. Biochen. J. 118, 11.

Chappel, S.C. \& Barraclough, C.A. (1977) Further studies on the regulation of FSH secretion. Endocrinology. $101,24-31$.

Cummins, L.J., O'Shea, T., Al-Obaidi, S.A.R., Bindon, B.M. \& Findlay, J.K. (1986) Increase in ovulation rate after immunization of Merino ewes with a fraction of bovine follicular fluid containing inhibin activity. J. Reprod. Fert. 77, 365-372.

Dluzen, D.E. \& Ramirez, V.D. (I987) Intermittent infusion of progesterone potentiates whereas continuous infusion reduces amphetamine stimulated dopamine release from ovariectomized estrogen-primed rat striatal fragments superfused in vitro. Brain Res. 406 , $1-9$

Dufour, J., Cahill, L.P. \& Mauléon, P. (1979) Short and long-term effects of hypophysectomy and unilateral ovariectomy on ovarian follicular populations in sheep. J. Reprod. Fert. 57, 301-309.

Findlay, J.K. \& Clarke, I.J. (1987) Regulation of the secretion of FSH in domestic animals. $J_{+}$Reprod. Fert., Suppl. 34, 27-37.

Findlay, J.K., Tsonis, C.G., Staples, L.D. \& Cahill, R.N.P. (1986) Inhibin secretion by the sheep ovary, $J$, Reprod Fert. 76, 751-761.

Findlay, J.K., Doughton, B., Robertson, D.M. \& Forage, R.G. (1989) Effects of immunization against recombinant bovine inhibin $\alpha$-subunit on circulating concentrations of gonadotrophins in ewes, $J$. Endocr. 114, RI-R4,

Findlay, J.K., Clarke, I.J. \& Robertson, D.M. (1990) Inhibin concentrations in ovarian and jugular venous plasma and the relationship of inhibin with follicle stimulating hormone and luteinizing hormone during the ovine estrous cycle. Endocrinology 126, 528-535.

Goding, J.R., McCracken, J.A. \& Baird, D.T. (1967) The study of ovarian function in the ewe by means of a vascular autotransplantation technique. $J$. Endocr. $39,37-52$.

Goodman, R.L., Pickover, S.M. \& Karsch, F.J. (1981) Ovarian feedback control of follicle-stimulating hormone in the ewe: evidence for selective suppression. Endocrinology 108, 772-777.

Henderson, K.M., Franchimont, P., Lecomte-Yerna, M.J., Hudson, N. \& Ball, K. (I984) Increase in ovulation rate after active immunisation of sheep with inhibin partially purified from bovine follicular fluid. $J$ Endocr. 102, 305-309.

Jonas, H.A., Salamonsen, L.A., Burger, H.G., Chamley, W.A., Cumming, I.A., Findlay, J.K. \& Goding, J.R. (1973) Release of FSH after administration of gonadotropin-releasing hormone or estradiol to the anestrous ewe. Endocrinology 92, 862-865.

Knight, P.G., Beard, A.J., Wrathall, J.H.M. \& Castillo, R.J. (1989) Evidence that the bovine ovary secretes large amounts of monomeric inhibin $\alpha$-subunit and its isolation from bovine follicular fluid, $J$ molec. Endocr. 2, 189-200.

Land, R.B. (1976) Sensitivity of the ovulation rate of Finnish Landrace and Blackface ewes to exogenous oestrogen. J. Reprod. Fert. 48, 217-218. 
Leversha, L.J., Robertson, D.M., de Vos, F.L., Morgan, F.J., Hearn, M.T.W., Wettenhall, R.E.H., Findlay, J.K., Burger, H.G. \& de Kretser, D.M. (1987) Isolation of inhibin from ovine follicular fluid. J. Endocr. 113, 213-221.

Lincoln, G.A., Lincoln, C.E. \& McNeilly, A.S. (1990) Seasonal cycles in the blood plasma concentrations of FSH, inhibin and testosterone, and testicular size in rams of wild, feral and domesticated breeds of sheep. J. Reprad. Fert. 88, 623-633.

Mann, G.E., McNeilly, A.S. \& Baird, D.T. (1989a) Source of inhibin secretion during the oestrous cycle of the sheep. J. Endoer. 123, 181-188.

Mann, G.E., Campbell, B.K., McNeilly, A.S. \& Baird, D.T. (1989b) Passively immunizing ewes against inhibin during the luteal phase of the oestrous cycle raises the plasma concentration of FSH $J$. Endocr. 123, 388-391.

Mann, G.E., Campbell, B.K., MeNeilly, A.S. \& Baird, D.T. (1990) The effects of passively immunizing ewes against inhibin and oestradiol during the follicular phase of the oestrous cycle. J. Endocr. 125, 417-424.

Martensz, N.D., Scaramuzzi, R.J. \& Van Look, P.F.A. (1979) Plasma concentrations of luteinizing hormone and follicle stimulating hormone during anoestrus in ewes actively immunized against oestradiol-17ß, oestrone or testosterone. J. Endocr. 81, 261-269.

Martin, G.B., Price, C.A., Thiery, J-C. \& Webb, R. (1988) Interactions between inhibin, oestradiol and progesterone in the control of gonadotrophins in the ewe. J. Reprod. Fert. 82, 319-328.

McNatty, K.P., Gibb, M., Dobson, C., Ball, K., Custer, J., Heath, D. \& Thurley, D.C. (1982) Preovulatory follicular development in sheep treated with PMSG and/ or prostaglandin. J. Reprod. Fert. 65, 111-123.

McNeilly, A.S. (1984) Changes in FSH and pulsatile secretion of LH during the delay in oestrus induced by treatment of ewes with bovine follicular fluid. $J$. Reprod. Fert. 72, I65-172.

McNeilly, A.S. (1985) Effects of changes in FSH induced by bovine follicular fluid and FSH infusion in the preovulatory phase on subsequent ovulation rate and corpus luteum function in the ewe. J. Reprod. Fert. 74, 661-668.

McNeilly, A.S. (1988) The control of FSH secretion. Acta endoct, Copenh, 288, 31-40.

McNeilly, A.S. \& Baird, D.T. (1989) Episodic secretion of inhibin into the ovarian vein during the follicular phase of the oestrous cycle in the ewe. J. Endocr.122, 287-292.

McNeilly, A.S., Fraser, H.M. \& Baird, D.T. (1984) Effect of immunoneutralization of $\mathrm{LH}$ releasing hormone on LH. FSH and ovarian steroid secretion in the preovulatory phase of the oestrous cycle in the ewe. $J$. Endocr. 101, 213-219.

MeNeilly, A.S., Swanston, I.A., Crow, W., Tsonis, C.G. \& Baird, D.T. (1989) Changes in the plasma concentrations of inhibin throughout the normal sheep oestrous cycle and after infusion of FSH. $J_{*}$ Endocr. 120, 295-305.

McNeilly, A.S., Picton, H.M., Campbell, B.K. \& Baird, D.T. (1991) Gonadotrophic control of follicle growth in the ewe.J. Reprod. Fert., Suppl.43, 177-186.

Miller, W.L., Knight, M.M., Grimek, H.J. \& Gorski, J. (1977) Estrogen regulation of follicle stimulating hormone in cell cultures of sheep pituitarics. Endocrinology 100, 1306-1316.

Miller, K.F., Critser, J.K. \& Ginther, O.J. (1982) Inhibition and subsequent return of FSH secretion following treatment with bovine follicular fluid in the ewe. Theriogenology 18,45-53.

Miyamoto, K., Hasegawa, Y., Fukuda, M., Nomura, M., Igarashi J., Kangawa, K. \& Matsuo, H. (1985) Isolation of porcine follicular fluid inhibin at $32 \mathrm{~K}$ Daltons. Biochem. Biophys. Res. Commun. 129, 396 403.

Narayana, K. \& Dobson, H. (1979) Effect of administration of antibody against $\mathrm{GnRH}$ on the preovulatory LH and FSH surges in the ewe. $J$. Reprod. Fert. $57,65-72$.

Pant, H.C. \& Rawlings, N.C. (1973) The effect of active immunization against oestradiol-17ß on plasma gonadotrophin concentrations in sheep. $J$. Reprod. Fert. $35,610-611$.

Rodgers, R.J., Stuchbery, S.J. \& Findlay, J.K. (1989) Inhibin in RNAs in ovine and bovine ovarian follicles and corpora lutea throughout the oestrous cycle and pregnancy. Molec. cell. Endocrinol. 62,95-101.

Salamonsen, L.A., Jonas, H.A., Burger, H.G., Buckmaster, J.M., Chamley, W.A., Cumming, I.A., Findlay, J.K. \& Goding, J.R. (1973) A heterologous radioimmunoassay for follicle stimulating hormone: application to measurement of FSH in the ovine estrous cycle and several other species including man. Endocrinology 93, 610-618.

Scaramuzzi, R.J., Davidson, W.G. \& Van Look, P.F.A. (1977) Increasing ovulation rate of sheep by active immunization against an ovarian steroid androstenedione. Nature, Lond. 269, 817-818.

Smeaton, T.C. \& Robertson, H.A. (1971) Studies on the growth and atresia of Graafian follicles in the ovary of the sheep. J. Reprod. Fert. 25, 243-252.

Sugino, K., Nakamura, T., Takio, K. Titani, K., Miyamoto, K., Hasegawa, Y., Igarashi, I. \& Sugino, H. (1989) Inhibin alpha-subunit monomer is present in bovine follicular fluid, Biochem. Biophys. Res. Commun. 159, 1323-1329.

Tsonis, C.G., Carson, R.S. \& Findlay, J.K. (1984) Relationships between aromatase activity, follicular fluid, oestradiol-17ß and testosterone concentrations, and diameter and atresia of individual follicles. $J$. Reprod. Fert. 72, 153-163.

Tsonis, C.G., McNeilly, A.S. \& Baird, D.T. (1986) Measurement of exogenous and endogenous inhibin in sheep serum using a new and extremely sensitive bioassay for inhibin based in inhibition of ovine pituitary FSH secretion in vitro. J. Endocr. 110, 341-352.

Tsonis, C.G, McNeilly, A.S. \& Baird, D.T. (1988a) Inhibin secretion by the sheep ovary during the luteal and follicular phases of the oestrous cycle and following stimulation with FSH, J. Endocr, 117, 283-291.

Tsonis, C.G., Baird, D.T., Campbell, B.K., Leask, R. \& Scaramuzzi, R.J. (1988b) The sheep corpus luteum secretes inhibin. J. Endoer. 116, R3-R5.

Tsonis, C.G., Baird, D.T., Campbell, B.K., Downing, J.A. \& Scaramuzzi, R.J. (1988c) Secretion of bioactive inhibin by the ovary of the Booroola Merino ewe with or without a copy of the fecundity $(F)$ gene. J. Endocr. 119, R5-R8. 
Webb, R. \& England, B.G. (1982) Identification of the ovulatory follicle in the ewe: associated changes in follicular size, thecal cell and granulosa cell luteinizing hormone receptors, antral fluid steroids and circulating hormones during the pre-ovulatory period. Endocrinology 110, 873-881.
Wrathall, J.H.M., McLeod, B.J., Glencross, R.G., Beard, A.J. \& Knight, P.G. (1990) Inhibin immunoneutralization by antibodies raised against synthetic peptide sequences of inhibin a-subunit: effect on gonadotrophin concentrations and ovulation rate in sheep. J. Endocr. (in press). 